\title{
ANALISIS KOMPETENSI PENELITI \\ PADA BALAI PENELITIAN DAN PENGEMBANGAN BUDIDAYA AIR PAYAU
}

\author{
Bimo Adi Prianggoro
}

Balai Penelitian dan Pengembangan Budidaya Air Payau, bimoadiprianggoro@gmail.com

\begin{abstract}
Abstrak
Persoalan kompetensi PNS menjadi isu pokok seiring program reformasi birokrasi. Diperlukan suatu sistem yang tepat untuk meningkatkan kompetensi PNS. Berdasarkan data kepegawaian, PNS yang menduduki jabatan Peneliti pada BPPBAP menunjukkan jumlah dominan. Jumlah tersebut diharapkan bisa diimbangi dengan penguasaan kompetensi sesuai yang disyaratkan. Kajian bertujuan untuk menganalisis tingkat kompetensi Peneliti pada BPPBAP. Untuk menganalisis kompetensi Peneliti diukur menggunakan 3 variabel yaitu pengetahuan, keterampilan, dan sikap dengan metode survey. Hasil penelitian menyatakan bahwa sebagian besar Peneliti telah mampu menguasai kompetensi yang disyaratkan. Disarankan agar pimpinan dapat mengalokasikan pelatihan bagi indikator kompetensi yang lemah serta anggaran untuk kegiatan pengembangan sumber daya manusia.
\end{abstract}

Kata Kunci: Kompetensi, Peneliti, BPPBAP

\begin{abstract}
The issue of the competence of civil servants become a central issue in line with the bureaucratic reform program. Required an appropriate system to improve the competence of civil servants. Based on personnel data, civil servants who occupied the post of Researchers at RICA shows the number of dominant. The amount is expected to be offset by a corresponding mastery of competencies required. This study aimed to analyze the level of Researchers competence at RICA. The researchers competence is measured using three variables, namely knowledge, skills, and attitudes with survey method. The research result states that most researchers have been able to master the competencies required. It is recommended that the leader can allocate training for competencies assessed indicator has weaknesses and budgets for human resource development activity.
\end{abstract}

Keywords: Competence, Researcher, RICA

\section{PENDAHULUAN}

Keberadaan sumber daya manusia mempunyai peran utama dalam setiap kegiatan organisasi. Walaupun didukung dengan sarana dan prasarana serta sumber dana yang berlebihan, tanpa dukungan sumber daya manusia yang handal, pelaksanaan kegiatan tidak akan terselesaikan dengan baik. Sumber daya manusia adalah aset yang paling penting dalam sebuah perusahaan atau organisasi. Aset sumber daya manusia dapat menjadi potensi bila dikelola dengan baik dan benar, tetapi akan menjadi beban apabila salah kelola. Pengelolaan sumber daya manusia ini akan mempengaruhi kinerja organisasi dan akan menghasilkan kualitas sumber daya manusia yang unggul. Kualitas sumber daya manusia menurut Ruky (2003:57) adalah tingkat pengetahuan, kemampuan, dan kemauan yang dapat ditunjukkan oleh sumber daya manusia. Tingkat itu dibandingkan dengan tingkat yang dibutuhkan dari waktu ke waktu oleh organisasi yang memiliki sumber daya manusia tersebut.

Sebagai langkah awal untuk mempersiapkan sumber daya manusia yang berkualitas, adalah dimulai dari proses rekrutmen dan seleksi yang sesuai dengan standar kompetensi yang telah ditetapkan. Standar kompetensi tersebut merupakan persyaratan minimal yang harus dipenuhi agar seorang karyawan bisa mengerjakan pekerjaannya dengan profesional dan sesuai dengan prosedur yang telah ditetapkan. Berbicara mengenai kompetensi, khususnya jika dikaitkan dengan PNS, maka tidak bisa terlepas dari Undang-Undang Nomor 5 Tahun 2014 tentang Aparatur Sipil Negara. Dalam Undang-Undang tersebut telah diamanatkan bahwa setiap PNS harus memiliki kompetensi sesuai dengan bidang tugasnya. Kompetensi tersebut diperlukan demi memberikan pelayanan pada masyarakat secara profesional, jujur, tanggap, cepat, tepat, akurat, berdaya guna, dan santun.

Merujuk pada pendapat Darsono dan Siswandoko (2011:123), kompetensi adalah perpaduan keterampilan, pengetahuan, kreativitas, dan sikap positif terhadap pekerjaan tertentu yang diwujudkan dalam bentuk kinerja. Sementara menurut Boulter et. al. dalam Sutrisno (2009:203) mengatakan bahwa kompetensi adalah suatu karakteristik dasar seseorang yang memungkinkan 
memberikan kinerja dalam pekerjaan, peran, dan situasi. Dari pendapat para ahli tersebut, maka bisa disimpulkan bahwa kompetensi adalah kemampuan dan karakteristik yang dimiliki oleh seorang pegawai berupa gabungan antara pengetahuan (knowledge), kecakapan atau keterampilan (skill) dan sikap (attitude) yang diperlukan dalam pelaksanaan tugas, sehingga dapat melaksanakan tugas secara profesional, efektif dan efisien.

Dalam peningkatan profesionalisme PNS, maka prasyarat kompetensi menjadi hal yang utama, sebagaimana diungkapkan oleh Ashari (2010:6), bahwa istilah profesional dan kompetensi selalu dipakai secara bersamaan atau kedua kata tersebut tidak dapat dipisahkan. Sehingga, peningkatan kompetensi untuk mewujudkan profesionalisme PNS merupakan tuntutan yang harus dipenuhi dalam mewujudkan clean government dan good governance. Namun pada kenyataannya, saat ini banyak ketidakpuasan dari masyarakat yang disebabkan oleh masih banyaknya PNS yang memiliki kompetensi yang rendah sehingga berakibat pada rendahnya profesionalisme dalam melayani masyarakat. Sebagaimana diungkapkan Tamin (2002:26), bahwa sering ditemui sorotan masyarakat mengenai profesionalisme PNS yang menandakan bahwa masyarakat belum puas terhadap pelayanan yang diberikan oleh PNS.

Meninjau berbagai hal di atas, maka Balai Penelitian dan Pengembangan Budidaya Air Payau (BPPBAP) sebagai salah satu Unit Pelaksana Teknis dari Kementerian Kelautan dan Perikanan, menyadari bahwa pemenuhan kompetensi merupakan faktor yang sangat penting dalam mencapai visi dan misi instansi. Salah satu metode yang diterapkan oleh BPPBAP adalah melakukan pengembangan kompetensi secara berkelanjutan. Sebagai instansi yang bergerak di bidang litbang, maka BPPBAP senantiasa dituntut untuk selalu meningkatkan kapasitas dalam pemenuhan kebutuhan litbang, terutama di bidang komoditas perikanan budidaya air payau. Dan hal tersebut juga sangat ditunjang oleh kompetensi pegawainya yang dituntut untuk selalu berkembang. Berdasarkan data kepegawaian, maka kondisi PNS di BPPBAP sebagai berikut:

Tabel 1. Kondisi SDM BPPBAP Berdasarkan Jabatan

\begin{tabular}{clcc}
\hline No & \multicolumn{1}{c}{ Jenis Jabatan } & Jumlah & Persentase \\
\hline 1 & Jabatan Struktural & 10 & $8 \%$ \\
2 & Jabatan Fungsional Tertentu & 82 & $65 \%$ \\
3 & Jabatan Fungsional Umum & 36 & $27 \%$ \\
\hline \multirow{2}{*}{ Total } & $\mathbf{1 2 8}$ & $\mathbf{1 0 0 \%}$ \\
\hline
\end{tabular}

Sumber: Data Kepegawaian per 1 Juli 2016

Berdasarkan tabel 1 di atas, diperoleh bahwa sebaran jabatan fungsional tertentu sangat mendominasi sebaran jabatan lingkup BPPBAP. Hal tersebut menunjukkan bahwa minat dan konsentrasi PNS dalam mengembangkan karirnya melalui jalur jabatan fungsional tertentu lebih dominan dan hal ini sesuai dengan amanat Undang-Undang Nomor 5 Tahun 2014 yang mengisyaratkan penguatan jabatan fungsional tertentu dalam pembinaan karir sebagai sarana untuk menuju profesionalisme PNS. Adapun sebaran jabatan fungsional tertentu di BPPBAP adalah sebagai berikut:

Tabel 2. Jenis dan Sebaran Jabatan Fungsional Tertentu Lingkup BPPBAP

\begin{tabular}{|c|c|c|c|}
\hline No & $\begin{array}{c}\text { Jabatan } \\
\text { Fungsional }\end{array}$ & Jenjang Jabatan & Jumlah \\
\hline \multirow[t]{5}{*}{1} & Peneliti & Peneliti Utama & 9 \\
\hline & & Peneliti Madya & 17 \\
\hline & & Peneliti Muda & 16 \\
\hline & & Peneliti Pertama & 11 \\
\hline & Teknisi & Teknisi Litkayasa Penyelia & 4 \\
\hline \multirow[t]{2}{*}{2} & Litkayasa & $\begin{array}{c}\text { Teknisi Litkayasa Pelaksana } \\
\text { Lanjutan }\end{array}$ & 9 \\
\hline & & Teknisi Litkayasa Pelaksana & 11 \\
\hline \multirow[t]{2}{*}{3} & Pustakawan & Pustakawan Madya & 1 \\
\hline & & Pustakawan Pelaksana Lanjutan & 1 \\
\hline 4 & Arsiparis & Arsiparis Pertama & 1 \\
\hline 5 & $\begin{array}{c}\text { Analis } \\
\text { Kepegawaian }\end{array}$ & $\begin{array}{l}\text { Analis Kepegawaian Pelaksana } \\
\text { Lanjutan }\end{array}$ & 1 \\
\hline \multirow[t]{2}{*}{6} & Pengelola PBJ & Pengelola PBJ Madya & 1 \\
\hline & & Total & 82 \\
\hline
\end{tabular}

Sumber: Data Kepegawaian per 1 Juli 2016

Berdasarkan data yang diperoleh dari tabel 2 di atas, maka dapat digambarkan bahwa jabatan fungsional Peneliti sangat mendominasi sebaran PNS lingkup BPPBAP. Hal tersebut tentu menjadi tantangan bagi pimpinan instansi untuk selalu memberikan konsentrasinya terhadap pengembangan kompetensi Peneliti untuk mendukung kebijakan Kementerian Kelautan dan Perikanan. Pengembangan kompetensi Peneliti menjadi salah satu prasyarat mutlak bagi BPPBAP untuk mencapai visi dan misi yang telah ditetapkan, sehingga BPPBAP akan mampu melahirkan hasil atau inovasi litbang di bidang perikanan budidaya air payau yang dapat memenuhi kebutuhan teknis stakeholder atau instansi terkait. Selain itu, hasil analisis kompetensi akan memberikan gambaran kinerja Peneliti sehingga akan diketahui mana aspek yang memiliki keunggulan maupun aspek yang harus dikembangkan demi memenuhi syarat kompetensi minimal yang ditetapkan sebagaimana yang dipersyaratkan 


\section{METODE}

Metode penelitian yang digunakan dalam penelitian ini adalah metode penelitian survei dengan pendekatan kuantitatif. Data yang terkumpul dianalisis dengan cara mendeskripsikan melalui tabel frekuensi dan persentase dengan menggunakan pendekatan statistik deskriptif. Populasi dan sampel yang ditetapkan dalam penelitian ini adalah 50 orang dengan menggunakan teknik sampling jenuh.

Prosedur pengambilan data dengan menggunakan pendekatan penelitian survei, dimana penelitian yang dilakukan langsung ke objek penelitian. Adapun teknik pengumpulan yang digunakan adalah kuesioner, wawancara, observasi, dan telaah pustaka terhadap dokumen/peraturan yang berkaitan dengan tema penelitian. Hasil kumulatif dari jawaban responden kemudian dianalisis berdasarkan perhitungan persentase jawaban responden.

\section{HASIL DAN PEMBAHASAN}

Hasil penelitian dengan menggunakan pisau analisis 3 variabel kompetensi sebagaimana diamanatkan pada Peraturan Kepala Lembaga Ilmu Pengetahuan Indonesia Nomor 4/E/2009 tentang Standar Kompetensi Jabatan Fungsional Peneliti dengan indikator sebagai berikut:

Tabel 3. Indikator Kompetensi Peneliti

\begin{tabular}{|c|c|c|}
\hline PENGETAHUAN & KETERAMPILAN & SIKAP KERJA \\
\hline $\begin{array}{l}\text { 1.Teknik } \\
\text { perumusan } \\
\text { kajian masalah } \\
\text { penelitian; } \\
\text { 2.Teknik } \\
\text { penelusuran } \\
\text { pustaka. } \\
\text { 3.Teknik } \\
\text { penyusunan } \\
\text { proposal; } \\
\text { 4.Teknik } \\
\text { pengumpulan } \\
\text { data } \\
\text { instrumen } \\
\text { penelitian. } \\
\text { 5.Teknik } \\
\text { pengolahan data } \\
\text { penelitian. } \\
\text { 6.Teknik } \\
\text { penyusunan } \\
\text { karya tulis ilmiah } \\
\text { 7.Teknik presentasi } \\
\text { ilmiah hasil } \\
\text { penelitian. } \\
\text { 8.Teknik } \\
\text { memimpin } \\
\text { kelompok } \\
\text { penelitian. } \\
\text { 9.Teknik } \\
\text { pembimbingan } \\
\text { dan pengajaran. }\end{array}$ & $\begin{array}{l}\text { 1.Mampu } \\
\text { berkomunikasi } \\
\text { dengan baik. } \\
\text { 2.Mampu } \\
\text { mengoperasikan } \\
\text { peralatan penelitian. } \\
\text { 3.Mampu mengolah } \\
\text { dan menganalisis } \\
\text { data. } \\
\text { 4.Mampu menulis } \\
\text { dalam bahasa } \\
\text { Indonesia. } \\
\text { 5.Mampu menulis } \\
\text { abstrak dalam } \\
\text { Bahasa Inggris. } \\
\text { 6.Mampu } \\
\text { mengoperasikan alat } \\
\text { bantu presentasi. } \\
\text { 7.Mampu memotivasi } \\
\text { dengan baik diri } \\
\text { sendiri dan orang } \\
\text { lain. }\end{array}$ & $\begin{array}{l}\text { 1.Jujur. } \\
\text { 2.Bertanggung } \\
\text { jawab. } \\
\text { 3.Disiplin. } \\
\text { 4.Dapat bekerja } \\
\text { sama. } \\
\text { 5.Kritis. } \\
\text { 6.Kreatif. } \\
\text { 7.Motivatif. } \\
\text { 8.Inovatif. }\end{array}$ \\
\hline
\end{tabular}

Sumber: Peraturan Kepala Lembaga Ilmu Pengetahuan Indonesia Nomor $4 / \mathrm{E} / 2009$
Berdasarkan hasil penelitian dengan menggunakan indikator kompetensi sebagaimana Tabel 3, maka dapat dijelaskan kompetensi Peneliti di Balai Penelitian dan Pengembangan Budidaya Air Payau secara keseluruhan, sebagaimana tabel 4 di bawah ini:

Tabel 4. Hasil Analisis Kompetensi Peneliti

\begin{tabular}{|c|c|c|c|c|c|c|}
\hline \multirow{2}{*}{ No } & \multirow{2}{*}{ Aspek } & \multicolumn{2}{|c|}{ Kumulatif Jawaban } & \multirow{2}{*}{$\begin{array}{c}\text { Sub } \\
\text { Variabel }\end{array}$} & \multicolumn{2}{|c|}{ Nilai Akhir (\%) } \\
\hline & & Mampu & $\begin{array}{l}\text { Belum } \\
\text { Mampu }\end{array}$ & & Mampu & $\begin{array}{l}\text { Belum } \\
\text { Mampu }\end{array}$ \\
\hline 1 & Pengetahuan & 648 & 252 & 9 & $72,00 \%$ & $28,00 \%$ \\
\hline 2 & Keterampilan & 502 & 198 & 7 & $71,71 \%$ & $28,29 \%$ \\
\hline 3 & Sikap & 516 & 284 & 8 & $65,25 \%$ & $34,75 \%$ \\
\hline
\end{tabular}

Sumber: Data Olahan Hasil Analisis Kuesioner Kompetensi Peneliti, 2016

Tabel 4 di atas menunjukkan bahwa tingkat kompetensi Peneliti pada Balai Penelitian dan Pengembangan Budidaya Air Payau (BPPBAP) diukur dengan menggunakan 3 dimensi, yaitu aspek pengetahuan, aspek keterampilan, dan aspek sikap. Hal tersebut menunjukkan bahwa sebagian besar Peneliti mampu menguasai kompetensi yang dipersyaratkan oleh Peraturan Kepala Lembaga Ilmu Pengetahuan Indonesia Nomor 4/E/2009. Walaupun demikian terdapat kendala yang menyebabkan Peneliti memiliki indeks kompetensi yang rendah pada beberapa aspek, yaitu kompetensi penyusunan karya tulis ilmiah yang menunjukkan $46 \%$ Peneliti yang mampu menguasai; dan kompetensi inovasi yang menunjukkan $44 \%$ Peneliti yang mampu menguasai indeks kompetensi tersebut.

Hasil observasi menunjukkan bahwa kelemahan tersebut lebih disebabkan karena kurangnya motivasi dan keinginan Peneliti untuk meningkatkan kemampuan karena menganggap kemampuannya sudah memenuhi persyaratan. Hal tersebut juga dipengaruhi dengan sedikitnya anggaran yang dialokasikan untuk menunjang kegiatan pengembangan sumber daya manusia, terlebih lagi dengan adanya penghematan atau realokasi anggaran untuk kepentingan yang sifatnya insidental. Hal tersebut senada dengan hasil wawancara dengan Bapak RS, yang mengungkapkan pendapatnya sebagai berikut:

"Sebenarnya kalau boleh jujur, kompetensi Peneliti kita lebih baik dari Satker lain. Namun masih banyak yang memiliki kelemahan. Kelemahan ini lebih banyak diakibatkan motivasi Peneliti yang rendah untuk melakukan continous improvement. Selain itu anggaran yang minim juga menyebabkan kelemahan itu terus terjadi. Dengan komposisi Peneliti yang besar harusnya pimpinan mengalokasikan dana yang lebih untuk pengembangan sumber daya manusia litbang (wawancara 19 Juli 2016).

Dari hasil wawancara dengan Bapak RS tersebut dapat dikatakan bahwa secara umum walaupun kompetensi Peneliti di BPPBAP sudah baik, namun 
memiliki kelemahan pada aspek tertentu. Kelemahan tersebut lebih disebabkan karena motivasi dari Peneliti untuk melakukan peningkatan kapasitas dan kemampuan masih rendah. Selain itu minimnya alokasi anggaran juga menjadi kendala dalam peningkatan kompetensi Peneliti. Minimnya anggaran tersebut disebabkan karena adanya penghematan atau realokasi anggaran untuk kepentingan yang sifatnya insidental. Selain itu, karena BPPBAP adalah instansi litbang yang luaran utamanya adalah hasil litbang, maka sebagian besar anggaran dialokasikan untuk kepentingan litbang. Walaupun demikian, pengembangan kompetensi Peneliti juga tidak bisa diabaikan begitu saja mengingat tanpa keberadaan Peneliti yang kompeten maka produk litbang yang dihasilkan juga tidak akan maksimal. Juga ditekankan tentang pentingnya uji kompetensi untuk mengetahui profil kompetensi Peneliti secara komprehensif sebagai bahan bagi kegiatan pengembangan sumber daya manusia. Uji kompetensi tersebut diharapkan akan dapat memberikan gambaran sejauh mana Peneliti menguasai aspek kompetensi yang sudah sesuai dan aspek yang perlu dikembangkan demi menghasilkan Peneliti yang memiliki kompetensi sesuai persyaratan.

Berdasarkan hasil penelitian yang telah disajikan di atas, maka dapat disampaikan bahwa Peneliti pada BPPBAP telah mampu menguasai kompetensi yang dipersyaratkan. Namun dalam penerapannya, masih diperlukan pembenahan pada kompetensi yang masih memiliki kelemahan, terutama pada aspek kompetensi penyusunan karya tulis ilmiah dan pengembangan inovasi litbang. Padahal kedua aspek tersebut sangat berpengaruh bagi seorang Peneliti untuk menghasilkan karya atau inovasi yang bermanfaat bagi perkembangan iptek kelautan dan perikanan. Kelemahan ini tentu harus segera diatasi agar dapat berdampak positif dalam peningkatan kinerja Peneliti demi pencapaian visi dan misi BPPBAP dalam mendukung pencapaian tujuan Kementerian Kelautan dan Perikanan.

Sudah menjadi keharusan bagi instansi yang bergerak di bidang litbang bahwa kompetensi Peneliti merupakan suatu hal yang penting untuk diperhatikan. Kompetensi seorang Peneliti akan membawa dampak yang signifikan bagi Peneliti tersebut dalam melaksanakan kegiatan dan merumuskan keputusan yang terkait dengan kegiatan litbangnya. Hal ini sesuai dengan pendapat Rivai (2009:143) yang mengemukakan bahwa kompetensi memiliki hubungan yang erat dengan kinerja. Jika seorang pegawai memiliki kompetensi yang memadai, maka dapat dipastikan bahwa pegawai tersebut akan menghasilkan kinerja yang tinggi pula. Sementara menurut Palan (2007:78), sebuah organisasi akan memperoleh manfaat melalui pegawainya yang kompeten karena sebagian besar kinerja berakar dari kompetensi yang optimal. Lebih lanjut Klemp (dalam Sudarmanto, 2005:67), mengemukakan bahwa kompetensi merupakan karakteristik mendasar yang menghasilkan kinerja unggul dan efektif dalam suatu pekerjaan. Kinerja pegawai diciptakan karena kemampuan kerja pegawai yang dimanifestasikan dalam bekerja adalah sangat baik. Berkaitan dengan hal tersebut bawa kinerja yang meningkat senantiasa didambakan oleh setiap organisasi, karena kinerja adalah hasil kerja yang dapat dicapai oleh seseorang atau sekelompok orang dalam suatu organisasi sesuai dengan tanggung jawab pegawai dalam rangka upaya mencapai tujuan organisasi. Kompetensi yang dimiliki pegawai mampu menciptakan dan membentuk kinerja pegawai yang pada akhirnya akan memberikan kontribusi bagi kinerja organisasi. Pernyataan ini didukung oleh Kamidin (2010:30) dari hasil penelitiannya yang mengemukakan bahwa kompetensi sangat berpengaruh terhadap prestasi kinerja pegawai. Hal tersebut juga berlaku untuk instansi litbang seperti BPPBAP. Kualitas kompetensi Peneliti yang memadai akan memberi konstribusi besar dan signifikan terhadap pencapaian kinerja organisasi

\section{PENUTUP}

\section{Simpulan}

Berdasarkan hasil pembahasan, maka dapat ditarik kesimpulan bahwa sebagian besar Peneliti pada Balai Penelitian dan Pengembangan Budidaya Air Payau sudah mampu menguasai kompetensi yang dipersyaratkan, terutama pada kompetensi pengetahuan dan keterampilan. Sedangkan untuk indikator sikap yang memiliki indeks yang cukup rendah lebih diakibatkan karena Peneliti belum sepenuhnya memiliki konsep inovasi dalam pengembangan hasil litbangnya. Sehingga produk litbang yang dihasilkan pun cenderung merupakan konsep pengembangan yang belum sepenuhnya bisa diaplikasikan di masyarakat. Adapun kendala dan permasalahan yang terjadi lebih disebabkan karena motivasi untuk meningkatkan kompetensi tersebut masih rendah dan anggaran yang disediakan untuk kegiatan pengembangan sumber daya manusia juga terbatas.

Disarankan bagi pimpinan untuk mengalokasikan anggaran yang memadai dalam upaya pengembangan kompetensi Peneliti, terutama kompetensi yang masih memiliki indeks yang rendah. Selain itu, diperlukan sebuah kebijakan dari Kementerian Kelautan dan Perikanan yang dapat mendorong Peneliti agar mampu menghasilkan konsep inovasi hasil litbang yang langsung dapat diaplikasikan di masyarakat, sehingga masyarakat langsung dapat menikmati produk litbang kelautan dan perikanan yang tepat guna. 


\section{DAFTAR PUSTAKA}

Ashari, Edy Topo. (2010). Memahami Karakteristik Pegawai Negeri Sipil Profesional. Jurnal Kebijakan dan Manajemen PNS 4 (2). p 1-5.

Darsono dan Siswandoko, Tjatjuk. (2011). Manajemen Sumber Daya Manusia Abad 21. Jakarta: Nusantara Consulting.

Kamidin, Masruhi (2010). Pengaruh Kompetensi Terhadap Prestasi Kerja Pegawai Sekretariat Daerah Kabupaten Bantaeng. Jurnal Economic Resources, 11, 29-30.

Palan, R. (2007). Competency Management: Teknik Mengimplementasikan Manajemen SDM Berbasis Kompetensi Untuk Meningkatkan Daya Saing Organisasi. Jakarta: PPM Group.

Rivai, Veithzal dan Ella Jauvani Sagala. (2009). Manajemen Sumber Daya Manusia Untuk Perusahaan. Jakarta: PT Raja Grafindo Persada.

Ruky, Achmad S. 2003. Sumber Daya Manusia Berkualitas Mengubah Visi Menjadi Realitas. Jakarta: Gramedia Pustaka Utama.
Sudarmanto. 2005. Kinerja dan Pengembangan Kompetensi SDM: Teori, Dimensi Pengukuran, dan Implementasi dalam Organisasi. Jakarta: Pustaka Pelajar.

Sutrisno, Edy. (2009). Manajemen Sumber Daya Manusia. Jakarta: Kencana.

Tamin, Feisal. 2002. Pedoman Pengembangan Budaya Kerja Aparatur Negara. Jakarta: Kementerian Pendayagunaan Aparatur Negara.

Peraturan Kepala Lembaga Ilmu Pengetahuan Indonesia Nomor 4/E/2009 tentang Standar Kompetensi Jabatan Fungsional Peneliti.

Peraturan Menteri Kelautan dan Perikanan Nomor PER.32/MEN-KP/2011 tentang Organisasi dan Tata Kerja Balai Penelitian dan Pengembangan Budidaya Air Payau

Undang - Undang Nomor 5 Tahun 2014 tentang Aparatur Sipil Negara. 